Print ISSN: 2288-4637 / Online ISSN 2288-4645

doi:10.13106/jafeb.2020.vol7.no9.201

\title{
Oil Prices and Terms of Trade of Saudi Arabia: An Empirical Analysis
}

\author{
Mohammad Imdadul HAQUE ${ }^{1}$, Mohammad IMRAN²
}

Received: June 23, 2020 Revised: July 05, 2020 Accepted: August 10, 2020

\begin{abstract}
Terms of trade is an important indicator of the welfare gains from international trade to the exporting country. Terms of trade of oil-exporting countries are hypothesized to depend primarily on oil prices. The study assesses the relation between oil prices and the terms of trade of Saudi Arabia. The study uses the Autoregressive Distributed Lag method to determine the cointegration between the country's terms of trade and oil prices for the period 2000-2018. The data for net barter terms of trade is taken from World Development Indicators and oil price is taken from Saudi Arabian Monetary Agency. The results show that oil prices and terms of trade are cointegrated and any disequilibrium between the two variables is corrected by $35 \%$ in a year. The study also reports a positive relationship between the two items, both in the short run and long run. Diagnostic tests indicate the model to be fit. The results suggest that, for a primarily oil-producing country like Saudi Arabia, the terms of trade depend on oil prices. The study fills the gap in the literature on the study of terms of trade for Saudi Arabia for the last few years, where there has been a high volatility in oil prices.
\end{abstract}

Keywords: Terms of Trade, Oil Prices, ARDL, Diversification, Saudi Arabia

JEL Classification Code: F14, N75, O24, Q43

\section{Introduction}

The rise of emerging economies like Brazil, Russia, China, and India after 2000 led to a huge increase in the demand for oil (Ruta \& Venables, 2012). It leads to an increase in revenue of oil-exporting countries with high current account surpluses. Though these revenues boosted the domestic economy of oil-producing countries there were issues with the absorption of these revenues into the economy as these economies are poorly diversified (Kamps \& Beck, 2009). Also, an increase in revenues led to an increase in imports. In fact, for oil-exporting countries, the elasticity of import demand with respect to income is greater

${ }^{1}$ First Author and Corresponding Author. Associate Professor, College of Business Administration, Prince Sattam Bin Abdulaziz University, Saudi Arabia [Postal Address: Al Kharj-11942, Saudi Arabia] Email: m.haque@psau.edu.sa

${ }^{2}$ College of Applied Business Administration, Al Muzahmiyah Branch, King Saud University, Saudi Arabia. Email: myunus@ksu.edu.sa

(c) Copyright: The Author(s)

This is an Open Access article distributed under the terms of the Creative Commons Attribution Non-Commercial License (https://creativecommons.org/licenses/by-nc/4.0/) which permits unrestricted non-commercial use, distribution, and reproduction in any medium, provided the
und original work is properly cited. than one (Clarida, 1994). Russia, United Arab Emirates, and Saudi Arabia shared two-third imports of the oil-exporting countries (ECB, 2007). But after 2014 there is a significant decline in oil prices, which led to a decline in import intensity of oil-exporting countries (Hesary et al. 2013).

In its report,the World Bank (2015) finds that since 2010 the innovation in the technique of production raised the efficiency in the production and utilization of the oil worldwide. It adversely affected the price of oil. The unprecedented fall in the price of oil forced the oil-exporting economies to reconsider their economic and fiscal policies to attain a higher level of economic growth. The sharp decline in oil prices make an adverse impact on the collection of revenues and public sector spending on long term project as well as the welfare projects of the oil-exporting countries. The factors responsible for the deterioration of the oil prices are geopolitical issues in the Middle East, sanctions against the Russian Federation, and conflicts in Sub-Saharan oil producers.

Terms of trade is an important trade-related parameter to decide the pattern of gains from trade between countries. There are many concepts of terms of trade. This study considers net barter terms of trade as provided by World Development Indicators (WDI, 2020). It defines net barter 
terms of trade index as "the percentage ratio of the export unit value indexes to the import unit value indexes". It considers 2000 as the base year. As it is an indicator of the welfare gains from international trade, favorable movements in the terms of trade lead to greater gains from trade, while unfavorable movements of terms of trade affect the gains of trade adversely. A favorable terms of trade represents an equal and proportionate increase in the export price, over the import, while the deterioration in the terms of trade represent the fall in the export price, over the imports (Debaere \& Lee, 2003). Improvement in terms of trade is a significant factor for the growth of an economy (Awel, 2012).

Saudi Arabia, the country of interest for this study, is a primarily oil-centered country. It accounts for $16 \%$ of the world's petroleum reserve and is the leading oil exporter. The economic growth of the country depends strongly on oil revenues (Haque \& Khan, 2019). The oil sector constitutes $43.21 \%$ of the total gross domestic product (GDP) in 2018. In the same year among the total exports, oil exports are $78.67 \%$ and non-oil exports is only $21.32 \%$ (SAMA, 2018). Oil revenues are crucial to the growth and development of the country. The terms of trade movements for Saudi Arabia are represented in Figure 1. It reached a maximum of 149.50 in 2005 , but declined to 82.08 in 2016 , only to recover to 115.27 in 2018. The terms of trade was lower than the base value of 2100 in the year 2000 only in 2001, 2002, 2015, and 2016 (WDI, 2020). This indicates that only in four out of the nineteen years under study, in only four years the import prices were higher than the export prices

In the year 2018, the total exports of Saudi Arabia are 1103900, while the total imports are 513993 in million Saudi Arabian Riyals. The percentage change in exports was $32.7 \%$. The percentage of changes in imports is $1.9 \%$. The highest export to the region in descending order is to Asian countries (53.03\%), European Union (13.42\%), North America (9.64\%), Gulf Cooperation Council (GCC) (9.25\%) followed by others. Imports were from the following region is descending order: Asia (31.95\%), European Union (25.84\%), North America (14.97\%), followed by others. The commodity group with the highest import was Machinery, Mechanical Appliances, Electrical Equipment \& Parts (21.62\%), followed by Transport Equipment (16.46\%), Products of Chemical \& Allied Industries (10.06\%), Base Metals \& Articles of Base Metals (8.55\%), and Vegetable Products $(6.41 \%)$. All other import categories constituted less than 5\% each SAMA, 2018).

The terms of trade of Saudi Arabia has been fluctuating along with the oil prices (Figure 1). This study identifies a gap in research on the terms of trade of oil-exporting countries particularly for Saudi Arabia over the last few years where there has been huge volatility in crude oil prices. The oil prices increase from 26.81 in 2000 to 95.86 in 2008. In 2009 it fell to 61.38. It recovered and reached 110.22 in 2012. It again fell drastically from 97.18 in 2014 to 49.85 in 2015 and further to 40.96 in 2016. By 2018 it somewhat recovered to 70.59. A similar movement is evident in terms of trade also. This concept of terms of trade assumes added importance for Saudi Arabia as it is trying to structurally transform its economy. It launched an ambitious Vision 2030 program in 2016 to move away from oil dependence. Toward this, the study moves with the objective of studying the dependence of Saudi Arabia's terms of trade on crude oil prices.

\section{Literature Review}

An increase in the oil price has a direct and positive impact on the economy of oil exporting countries where, as it puts a negative and direct impact on oil importing economies. The consumption demand and investment demand are affected by the variation in the oil price (Ghalayini, 2011). On the other hand, an increase in oil prices raises the cost of the production, rate of the profits and returns from the new investment, but at the same time, it raised disposable income. Since oil is major contributor to the government

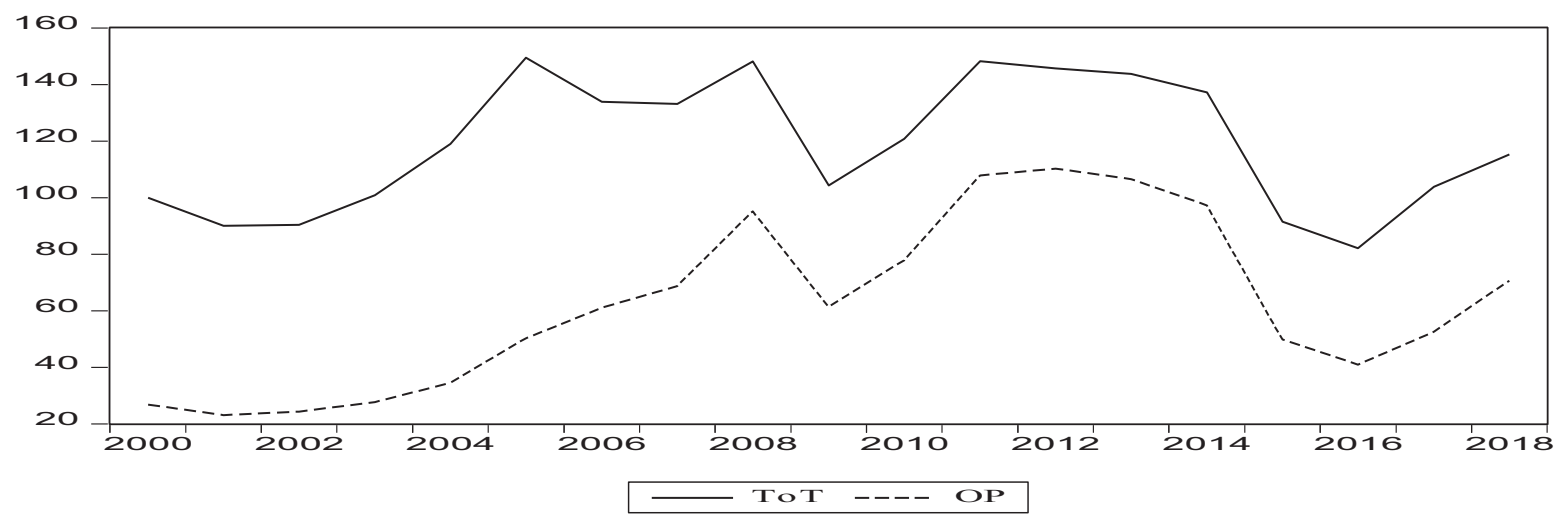

Figure 1: Terms of trade and oil prices 
revenues of the oil-exporting countries like the Saudi Arabia, a fall in the price leads to a decline in the export revenues and the government expenditure whereas an increase in the oil price accelerates the pace of economic growth of the oilexporting countries via export earnings and terms of trade effect (Berument et al., 2010). Therefore, it can be said that an increase in oil price has a positive and direct impact on the oil-exporting countries, while oil-importing countries have an adverse impact on their economic growth (Oriakhi \& Osaze, 2013).A positive indirect effect of the oil-exporting countries provides a scope to increase the revenues from the oil, but at the same time it also makes a room for the oilimporting countries to raise their exports to minimize their net loss (Bjornland, 2009).

In a related study, Hesary et al. (2013) found that the positive direct effect of oil price shocks on the economy of the oil-exporting countries. It means those countries who can increase the supply of the oil are in the benefit. The indirect benefits of the oil price shocks on most of the oil exporting countries are negative, economic sanctions against the Russian Federation and Iran, since 2014 is able to control exogenous shocks, maybe one of the important reasons for the low impact on the indirect benefits of the oil exporting countries. On the other hand, most of the European countries, as an importers of the oil, have registered an adverse impact of the oil prices on the GDP growth rate, while, East Asian economies are able to negotiate their imports with increasing the export to the oil-exporting countries, and they recorded a significant effect on their GDP.

Saudi Arabian and Russian economies were vulnerable after the reduction of oil prices since 2014. Despite the fall in the price of the crude oil, Saudi Arabia has an edge over Russia in the export market, because of the lower cost of production than Russia. The collapse of the Organization of the Petroleum Exporting Countries (OPEC) in 1986, the financial crisis of 2008 and again conflicts in OPEC in November 2014, created the problem for the oil-exporting countries. As a result of this oil prices drop, it makes the multiplier effects on their economy. After this event,Saudi Arabia raised the production of oil, but it fails to cover the loss of the revenues, which appeared due to the fall in the price (Bradshaw et al. 2019).

Over the last two decades, technological advancement has made extraction economical. Low oil prices facilitate supply chain linkages with oil related chemical and plastic manufacturing sector (Hojjat, 2014). Fluctuations in oil prices have both microeconomic impact and macroeconomic level. The microeconomic impacts can be felt on production costs, company earnings, dividend distribution and likewise. The macroeconomic impacts are on exchange rate, inflation, unemployment, interest rates and overall economic growth (Echchabi \& Azouzi, 2017). An increase in oil prices results in transfer of wealth to oil exporters from oil importers. Once these oil revenues are invested in the economy it further stimulates economic growth (Parsva \&Lean, 2017).

The volatility in oil prices is a big challenge for policymakers of the oil-exporting countries. The increase in the demand for oil and other commodities since 1971 forced a rise in the prices of oil.The unprecedented increase in oil revenues provides the room to increase the level of investment. But the oil-producing countries have experienced a low level of investment opportunities in the manufacturing sector. Therefore, the banks find the scope to finance import and consumer goods. The adverse effect of the oil revenues enables the inefficient use of the resources in the absence of the mature institutions, which neutralize the gain of the income from oil (Kilian, 2009).

In the analysis of the dynamics of macroeconomic variables,Rotemberg and Woodford (1996) predicted the uncertainty of the future supply of oil. The uncertainty of the future oil market and the shortage of supply affected the spot price of the oil (Alquist \& Kilian, 2010). Since oil is used as an important factor of production, an increase in the oil price raises the cost of the product, which leads to creating a disturbance on the supply side of the economy. The reduction in the supply of the production of oil as an increase in the prices is refuted by Islam (2012). In another study,Santis (2003) attempted to assess the numerical quantification of the impact of demand for crude oil and supply shocks on the prices, output, profits, and welfare in Saudi Arabia. The study reveals that the simulation of the supply shocks of oil has not a great effect on the oil price. This is because shortrun supply shocks are partly offset by the world and also affected the long-term marginal revenues of Saudi Arabia.

The utilization and production of unconventional oil, geopolitical risks, and an appreciation of the US dollar are important reasons for the worsening demand of crude oil at a global level, which leads to a significant policy shift of the OPEC, to stop the fall in the oil prices. The economic performance of the oil-exporting countries is adversely affected by the increase in the oil prices since it provides structural changes in their economy in the favor of oil and non-traded sectors and less importance on the agriculture and manufacturing sectors. On the other hand, the rise in oil revenues appreciated the currencies, which lead to expensive exports and cheaper imports. The low price of the imports provides an opportunity to increase the share of exports to the oil-importing countries, while it kills the domestic industry of the oil-exporting countries. In oil-exporting countries, the oil revenues control government revenues, gross investment, and other economic activities (Sayed,2018).

The increase in the oil price is a reason for worsening of the terms of trade of oil-importing countries and improving the terms of trade of oil-exporting countries via the transfer of wealth have not established a strong impact on economic growth. However, the increase in oil prices worsens the 
terms of trade of the oil-importing countries, but it also affects the international demand-supply and inflation. In the macroeconomic analysis of the Saudi Arabia over the period of 1980-2000 we observed that there is a small impact of the changes in oil prices on the terms of trade in the short run. However, the output is vulnerable to the shock of the terms of trade (Aleisa \& Dibooglu, 2004). An increase in oil prices deteriorate the terms of trade of the oil-importing countries (Backus \& Crucini, 2000). The low-price elasticity of demand for oil is a greater cause of the deficit in the balance of trade of oil-importing countries (Bodenstein \& Guerrieri, 2011).

An increase in oil price benefits oil exporters and improves current account balances, but it may impact the imports as oil producer's propensity to consume is smaller than the propensity to consume oil importers (Mussa, 2000). The variation in the oil prices makes favorable terms of trade for the oil-exporting countries, while it results in unfavorable terms of trade for the oil-importing countries (Mirfachi,2006). The terms of trade is heavily influenced by oil price shocks, which make the export earnings unstable (Naziri et al., 2015). Positive price shocks in oil deteriorate the terms of trade of oil-importing countries, but it also leads to a transfer of wealth to oil-exporting countries. This leads to increased growth in oil-exporting countries, which finally end up in importing more from oil-importing countries (Allegret et al., 2015). The oil exports of Saudi Arabia is positively associated with the economic growth of the country both in the long run and the short run, while import was having a negative relationship with the economic both in the short run and long run (Sultan \& Haque, 2018)

Oil price shocks lead to high macroeconomic volatility in the GCC region (Arezki \& Nabil, 2012). The growth of the oil sector also contributed to an increase in the exports as well as the imports of Saudi Arabia by the many folds (Alhowaish, 2014). Also, the exports and imports of Saudi Arabia are found to be cointegrated (Haque, 2015). Therefore, it can be said that the economy of the country depends on the performance of the oil sector. The prices of crude oil are fluctuating since the 1970s. The oil price shocks put an indirect effect on the GDP of the Saudi Arabia (Foudeh, 2017). In another study, Yousif and Alsultan (2018) found a negative correlation between oil prices and the GDP of Saudi Arabia. The reason for this relation is explained as the high oil price decreases the demand for the oil, which adversely affects the revenue of the government and the real growth rate of the GDP. Thus, heavy dependence on oil creates volatility in the economy.

\section{Research Methods and Materials}

The study uses the data for the period 2000 to 2018 for comprehending the relationship between terms of trade and oil prices. The data for net barter terms of trade is taken form
World Development Indicators (WDI). The data for oil prices is taken from Saudi Arabian Monetary Agency (SAMA). The oil prices are of Arabian Light variety. The data is first checked for stationarity using the Augmented Dickey-Fuller (ADF) test. Here, the null hypothesis is that the data is not stationary. Next, as the sample is small, the study proposes to use Autoregressive Distributive Lag (ARDL) method to look for a cointegrating relationship between the two variables. An added advantage of using this model is that it can be used irrespective of the condition that the variables are stationary at the level or first difference or one variable is stationary at the level and the other is stationary at first difference. Also, using ARDL for small samples is recommended by Pesaran and Shin (1999) and Narayan and Smyth (2012).The ARDL model is estimated by the given below equation:

$$
\begin{aligned}
\Delta \ln T o T_{t}= & \beta_{0}+\beta_{1} \ln T o T_{t-1}+\beta_{2} \ln O P_{t-1} \\
& +\sum_{i=1}^{p} \varphi_{i} \Delta \ln T o T_{t-i} \\
& +\sum_{j=0}^{q} \varphi_{j} \ln O P_{t-j}+\varepsilon_{t}
\end{aligned}
$$

Here, ToT stands for terms of trade and OP stands for oil prices. $\beta_{i}$ are the long run multipliers and $\varepsilon_{t}$ is the white noise error term. This equation is estimated and is tested for the presence of long run relationship using F-test for joint significance using the following hypothesis:

$$
H_{0}: \beta_{1}=\beta_{2}=0 ; H_{0}: \beta_{1} \neq \beta_{2} \neq 0
$$

Once cointegration is established the long run estimation is done through:

$$
\ln T o T_{t}=\beta_{0}+\sum_{i=1}^{p} \beta_{i} \ln T o T_{t-i}+\sum_{j=0}^{q} \beta_{j} \ln O P_{t-j}+\varepsilon_{t}
$$

where $\beta_{s}$ are the long run estimates.

And the short run is specified as:

$$
\begin{aligned}
\Delta \ln T o T_{t}= & \beta_{0}+\sum_{i=1}^{p} \varphi_{i} \Delta \ln T o T_{t-i} \\
& +\sum_{j=0}^{q} \varphi_{j} \Delta \ln O P_{t-j} \\
& +\theta E C M_{t-1}+\varepsilon_{t}
\end{aligned}
$$

where $\varphi_{s}$ are the short run estimates and $\theta$ is the coefficient of the error correction term.

Finally, residual diagnostic tests are performed. The serial correlation test is done with the null hypothesis that there is no serial correlation. The heteroscedasticity test is done with the null hypothesis that is no heteroscedasticity. The normality test is done with the null hypothesis that that the residuals are normally distributed. The CUSUM 
graphs are drawn to check if the model is stable. And finally Ramsey test is done with the null hypothesis that there is no misspecification in the model.

\section{Results and Discussion}

A preliminary visit to the data reveals that the net barter terms of trade has a mean of 11.836 with the base value of 100 in the year 2000. The terms of trade fluctuated from a maximum value of 149.50 to 82.05 . Similarly, the oil prices also fluctuated between 110.22 and 29.84 with a mean value of 62.45 US dollars per barrel. While the terms of trade were negatively skewed, oil prices are positively skewed. The deviation in the prices of oil prices is greater than that in terms of trade (Table 1).
The study progresses with the identification of the stationary characteristics of the time series data. The results of Augmented Dickey Fuller test indicate that oil price is non-stationary at level, but is stationary at first difference (constant; and none). Terms of trade is stationary at level (None) (Table 2). As the data is stationary at level and at first difference, this study proceeds with the ARDL method for further analysis.

The results of ARDL estimation is provided in Table 3. The results of ARDL estimation indicates that there is exists a cointegrating relationship between terms of trade and oil prices as the F-statistic of the Bounds test (5.43) is higher than the upper bound value (4.16) at 5\% level of significance.

Table 1: Descriptive statistics

\begin{tabular}{|l|c|c|c|c|c|c|c|}
\hline Variable & Mean & Median & Maximum & Minimum & Std. Dev. & Skewness & Kurtosis \\
\hline ToT & 118.8316 & 119.0026 & 149.5085 & 82.08547 & 23.15536 & -0.040031 & 1.539918 \\
\hline OP & 62.45105 & 61.10000 & 110.2200 & 23.06000 & 29.84758 & 0.276906 & 1.799417 \\
\hline
\end{tabular}

Table 2: ADF test results

\begin{tabular}{|l|c|c|c|c|}
\hline & test statistic & P-value & test statistic & \multicolumn{3}{c|}{ dOP } \\
\hline & \multicolumn{2}{|c|}{ OP } & \multicolumn{3}{c|}{0.0431} \\
\hline Constant & -1.523566 & 0.4992 & -3.132195 & 0.1098 \\
\hline Constant, Linear Trend & -1.300850 & 0.8541 & -3.239953 & 0.0043 \\
\hline None & 0.611860 & 0.8391 & -3.077692 & dToT \\
\hline & \multicolumn{2}{|c|}{ ToT } & & -3.762318 \\
\hline Constant & -1.972371 & 0.5764 & -3.491300 & 0.0523 \\
\hline Constant, Linear Trend & 0.105293 & 0.7036 & -3.491300 & 0.0020 \\
\hline None & -3.329893 & 0.0334 & & 0.0020 \\
\hline
\end{tabular}

Table 3: ARDL estimates and Bound test results

\begin{tabular}{|l|c|c|c|c|}
\hline Variable & Coefficient & Std. Error & t-Statistic & Prob. \\
\hline LTOT(-1) & 0.64623 & 0.102374 & 6.312436 & 0.000 \\
\hline LOP & 0.582802 & 0.050423 & 11.55824 & 0.000 \\
\hline LOP(-1) & -0.50225 & 0.056484 & -8.89191 & 0.000 \\
\hline C & 1.338292 & 0.380175 & 3.520199 & 0.0034 \\
\hline \multicolumn{7}{|c|}{ R-squared: 0.940258; F-statistics: 73.44645; Prob(F-statistics):0.000000 } \\
\hline \multicolumn{5}{|c|}{ Model selection:-Maximum lags: 4 (Automatic selection); Akaike info criterion; ARDL(1,1) } \\
\hline Bounds test & Value & Significance & Lower bound 95\% & Upper bound 95\% \\
\hline \multicolumn{7}{|c|}{$5 \%$} & 3.62 \\
\hline F-statistic & 5.434173 & 5.16 & \\
\hline
\end{tabular}


The results estimate that there is a significant long-run relationship between the two variables as the associated p-vale for the t-statistic is 10.01, which is less than the 0.05 . A one percent increase in oil prices leads to 0.22 percent increase in terms of trade. The results also indicate a short run association as the value is less than 0.05 . A one-percent increase in oil prices increase the terms of trade by 0.58 . The short run coefficient is bigger than the long-run coefficient. The speed of adjustment indicated by the error correction terms is -0.35 . As it is significant, this implies that any disequilibrium between the two variables will be corrected by $35 \%$ in a year (Table 4 ).

Table 4: ARDL estimation results

\begin{tabular}{|l|c|c|c|c|}
\hline \multicolumn{5}{|c|}{ Long run relationships } \\
\hline Variable & Coefficient & Std. Error & t-Statistic & Prob. \\
\hline OILP1 & 0.227697 & 0.07705 & 2.955237 & 0.0104 \\
\hline C & 3.782943 & 0.30845 & 12.26436 & 0.000 \\
\hline \multicolumn{5}{|c|}{ Short run relationship } \\
\hline D(OILP1) & 0.582802 & 0.04324 & 13.47784 & 0.000 \\
\hline CointEq(-1)* & -0.35377 & 0.08196 & -4.31642 & 0.0007 \\
\hline
\end{tabular}

Table 5: Diagnostic tests

\begin{tabular}{|l|l|c|c|}
\hline Item & \multicolumn{1}{|c|}{ Diagnostic test } & Test statistic & P-Value \\
\hline Serial Correlation & Breusch-Godfrey LMtest & 0.180257 & 0.9138 \\
\hline Normality & Jarque-Bera & 0.791559 & 0.673155 \\
\hline Heteroskedasticity & Breusch-Pagan-Godfrey & 5.588568 & 0.1334 \\
\hline Model Specification & Ramsey RESET Test & 1.052151 & 0.3119 \\
\hline
\end{tabular}

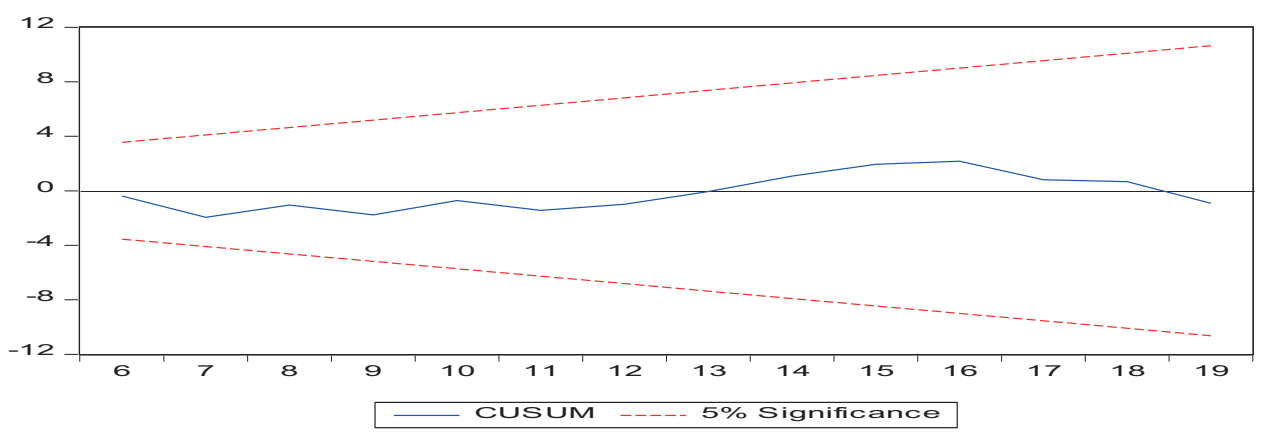

Figure 2: CUSUM graph

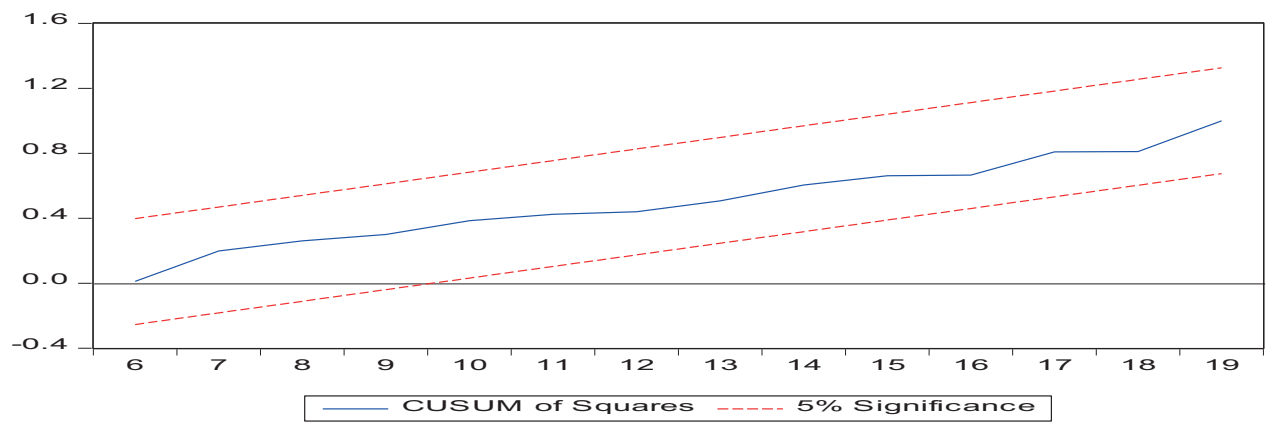

Figure 3: CUSUM square graph 
The results negate the presence of serial correlation in the model as the associated p-value of the BreuschGodfrey Lagrange Multiplier test is 0.91 . This leads to the acceptance of the null hypothesis of no serial correlation. The results also indicate that the residuals are normally distributed as the $p$ value of Jarque-Bera test is 0.37 , which is more than 0.05 . The results negate the presence of heteroscadisticity in the model as the associated p-value of the Breusch-Pagan-Godfrey test is 0.91 . This leads to the acceptance of the null hypothesis of homoscadisticity. Also, the model is correctly specified as the Ramsey reset test has the p-value of 0.31 indicating the acceptance of null hypothesis of no misspecification (Table 5). Also, the model is stable and free from structural breaks as indicated by the CUSUM and CUSUM square graphs (Figure 2 and 3 ).

\section{Conclusions}

The best way to avoid a deterioration of terms of trade is upgrading varieties and improving the quality of the items in the export basket (Debaere \& Lee, 2003). But a major portion of Saudi Arabian export consists of oil exports $(78.67 \%$ in 2018). This makes the terms of trade of Saudi Arabia greatly dependent on oil prices. The result of this study supports the observations of Aleisa and Dibooglu (2004) and Naziri et al. (2015) that oil prices strongly influence the terms of trade. This study also supports the observations of Mussa (2000) and Allegret et al. (2015) that in oil-exporting economies, the oil price has a positive impact on the terms of trade. And this study negates the observation of Mirfachi (2006), which was inconclusive about the impact of oil prices on the terms of trade of Saudi Arabia.

Stability in oil prices is important in reducing variations in the terms of trade. But an individual country on its own cannot affect the oil prices hugely. It can at the most increase or decrease the supply, but it does not have much of an effect as other exporters may not agree to this decision. Also, during economic downturns like the financial crisis of 2008 or unexpected events with a global outlook like the COVID-19 pandemic of 2020, oil prices are highly susceptible. The way out is diversification of the export basket. Export diversification to improve terms of trade is also recommended by Naziri et al. (2015).

There is a further scope of work in terms of understanding the relation of terms of trade with other macroeconomic factors like trade openness, exchange rate, inflation rate, and likewise. There is also a requirement of a longer data set, which unfortunately is not available. WDI has data only from the year 2000 to 2018 . Nevertheless, this study fills the gap in the literature by studying the impact of oil prices on the terms of trade of Saudi until the latest data available.

\section{References}

Aleisa, E.A., \& Dibooglu, S. (2002). Sources of real exchange rate movements in Saudi Arabia. Journal of Economics and Finance, 26, 101-110. http://dx.doi.org/10.1007/BF02744455

Allegret, J.P., Mignon, V. \& Sallenave, A. (2015). Oil price shocks and global imbalances, Lessons from a model with trade and financial interdependencies. Economic Modelling, 49, 232-247. https://doi.org/10.1016/j.econmod.2015.04.009

Alquist, R., \& Kilian, L. (2010). What do we learn from the price of crude oil futures? Journal of Applied Econometrics, 25, 539-573. http://dx.doi.org/10.1002/jae.1159

Arezki, R., \& Nabli, K. (2012). Natural resources, volatility, and inclusive growth, perspective from the Middle East and North Africa. IMF Working Paper 12/111. Washington, DC: International Monetary Fund.

Atkeson, A., \& Kehoe, P.J. (1999). Models of energy use, PuttyPutty versus Putty-Clay. American Economic Review, 89, 1028-1043. http://dx.doi.org/10.1257/aer.89.4.1028

Awel, A. M. (2012). Terms of trade volatility and economic growth in Sub-Saharan Africa. MPRA Paper No. 45453. University Library of Munich, Germany. https://mpra.ub.uni-muenchen. de $/ 45453 /$

Backus, D., \& M. Crucini (2000). Oil Prices and the terms of trade. Journal of International Economics, 50, 185-213. https://doi. org/10.1016/S0022-1996(98)00064-6

Berument, H., Ceylan, N., \& Dogan, N. (2010) The impact of oil price shocks on the economic growth of selected MENA countries. Energy Economics, 31, 149-176. http://dx.doi. org/10.5547/ISSN0195-6574-EJ-Vol31-No1-7

Bjornland, H. C. (2009). Oil price shocks and stock market booms in an oil exporting country. Scottish Journal of Political Economy, 56(2), 232-254. http://dx.doi.org/10.1111/j.14679485.2009.00482.x

Bodenstein, M., \& Guerrieri, L. (2011). Oil Efficiency, Demand, and Prices: a Tale of Ups and Downs. International Finance Discussion Paper No. 1031. Washington, DC: Board of Governors of the Federal Reserve System.

Bradshaw, M. Graaf, T. V.D., \& Connolly, R.(2019). Preparing for the new oil order? Saudi Arabia and Russia. Energy Strategy Reviews, 26, 1003742. https://doi.org/10.1016/j. esr.2019.100374

Clarida, R. H. (1994). Cointegration, Aggregate Consumption, and the Demand for Imports: A Structural Econometric Investigation. American Economic Review, 84(1), 298-308. https://www.jstor.org/stable/2117985

Debaere, P., \& Lee, H. (2003). The real-side determinants of countries' terms of trade: A panel data analysis. Retrieved January 10, 2020 from: https,//faculty.darden.virginia.edu/ debaerep/pdf/termsWP.pdf

ECB. (2007). Oil-exporting countries, key structural features, economic developments and oil revenue recycling, Monthly 
Bulletin, July. Retrieved February 5, 2020 from: https,//www. ecb.europa.eu/pub/pdf/other/pp75-86_mb200707en.pdf

Echchabi, A., \& Azouzi, D. (2017). Oil Price Fluctuations and Stock Market Movements: An Application in Oman. Journal of Asian Finance, Economics and Business, 4(2), 19-86. http:// dx.doi.org/10.13106/jafeb.2017.vol4.no2.1

Foudeh, M. (2017). The long run effects of oil prices on economic growth: The case of Saudi Arabia. International Journal of Energy Economics and Policy, 7(6), 171-192.

Ghalayini, L. (2011). The interaction between oil price and economic growth. Middle Eastern Finance and Economics, 13, 127-141.

Haque, M.I. (2015). Are Exports and Imports cointegrated in Saudi Arabia. Applied Econometrics and International Development, 15(1), 111-130.

Haque, M.I., \& Khan, M.R. (2019) Role of oil production and government expenditure in improving Human Development Index, Evidence from Saudi Arabia, International Journal of Energy Economics and Policy, 9(2), 251-256.

Hesary, F.T., Yoshino, N., Abdoli, A., \& Farzinvash, A. (2013). An estimation of the impact of oil shocks on crude oil exporting economies and their trade partners. Frontiers of Economics in China, 8(4), 571-591.

Hojjat, T. A. (2014). Economic Impacts of Energy Development on Domestic Economy. Journal of Asian Finance, Economics and Business, 1(1), 41-45. https://doi.org/10.13106/jafeb.2014. vol1.no1.41.

Islam, R. (2012). Oil price shocks and macroeconomy, the role for precautionary demand and storage. MPRA Paper No. 42351, University Library of Munich, Germany. https://mpra.ub.unimuenchen.de/42351/1/MPRA_paper_42351.pdf

Kamps, A., \& Beck, R. (2009). Petrodollars and imports of oil exporting countries. Working Paper Series 1012. Frankfurt, Germany: European Central Bank.

Kilian, L., (2009). Not all oil price shocks are alike, disentangling demand and supply shocks in the crude oil market. American Economic Review, 99(3), 1053-1069. http://dx.doi.org/10.1257/ aer.99.3.1053

Mirfachi, A. (2006). Oil prices and terms of trade- A comparison between Saudi Arabia and the United States. Master Thesis. International Business School, Jonkoping University. Jönköping, Sweden.

Mussa, M. (2000). The impact of higher oil prices on the global economy. Washington, DC: International Monetary Fund. Available at: https://www.imf.org/external/pubs/ft/oil/2000/ oilrep.PDF

Narayan, P. \& Smyth, R. (2012). Trade liberalization and economic growth in Fiji. An empirical assessment using the ARDL approach. Journal of the Asia Pacific Economy, 10(1), 96-115. https://doi.org/10.1080/1354786042000309099

Naziri, M.K., Nemati, M., Darabi, H., \& Raisi , G. (2015). Review of the Terms of Trade in Selected Countries and Iran. International Journal of Life Sciences, 9(6), 75-78. https://doi. org/10.3126/ijls.v9i6.12742

Oriakhi, D.E., \& Osaze, I. (2013). Oil price volatility and its consequences on the growth of the Nigerian economy: An examination (1970-2010). Asian Economic and Financial Review, 3(5), 683-702.

Parsva, P.,\& Lean, H. H. (2017). Multivariate Causal Relationship between Stock Prices and Exchange Rates in the Middle East. Journal of Asian Finance, Economics and Business, 4(1), 25-38. http://dx.doi.org/10.13106/jafeb.2017.vol4.no1.25

Pesaran, M. H., \& Shin, Y. (1999). An Autoregressive Distributed Lag Modelling approach to cointegration analysis. In: S. Strom, (ed.) Econometrics and Economic Theory in the 20th Century, The Ragnar Frisch Centennial Symposium. Cambridge, UK: Cambridge University Press.

Rotemberg, J., \& Woodford M. (1996). Imperfect competition and the effects of energy price increases on economic activity. Journal of Money, Credit, and Banking, 28, 550- 77.

Ruta,M., \& Venables, A.J. (2012). International trade in natural resources, practice and policy, Annual Review of Resource Economics, 4,331-352

SAMA. (2018) Annual Statistics 2018, Saudi Arabian Monetary Agency. Retrieved January 10, 2020 from: http://www.sama. gov.sa/en-US/EconomicReports/Pages/YearlyStatistics.aspx

Santis, R. A. (2003). Crude oil price fluctuations and Saudi Arabian behaviour. Energy Economics, 25(2), 155-173. https://doi. org/10.1016/S0140-9883(02)00106-8

Sayed, M. A. (2018). The impact of oil prices on the economic growth and development in the MENA countries. MPRA Paper No. 89073. University Library of Munich, Germany. https:// mpra.ub.uni-muenchen.de/89073/

Sultan, Z.S., \& Haque, M.I. (2018). Oil exports and economic growth: An empirical evidence from Saudi Arabia, International Journal of Energy Economics and Policy, 8(5), 281-287

WDI.(2020). The World Bank Indicator Database. Retrieved January 120, 2020 from: https://data.worldbank.org/country/ saudi-arabia

World Bank (2015). MENA quarterly economic review, plunging oil prices. Washington, DC: The World Bank.

Yousif, I. A. K., \& Alsultan M. M. (2018).Relationship between oil price fluctuation and macroeconomic performance in Saudi Arabia. Scholars Bulletin, 4(11), 822-832. 